\title{
Nip/Tuck well past its best before
}

$\mathrm{H}$ ere we go again. More extreme comedy about mastopexy, blepharoplasty and rhytidectomy, about those who perform them and those upon whom they are performed.

In the resolution of a midseason cliffhanger, plastic surgeon Sean McNamara (Dylan Walsh) operates on his daughter, Annie (Kelsey Lynn Batelaan), in his private clinic. Annie is recovering from injuries suffered in a paparazzi-induced car crash, which also injured Sean's partner, hunky lothario Dr. Christian Troy (Julian McMahon). Cue the O'Jays' soul classic Back Stabber: "They smile in your face ..." Unbeknownst to Sean, he is being stalked by the deranged Colleen Rose (Sharon Gless, formerly Cagney or Lacey), a bogus talent agent and teddy-bear fetishist, who represented him when he had a role in a TV series called Hearts \& Scalpels.

"All the time they want to take your place." Colleen sneaks into the operating room brandishing a giant blade apparently on loan from Halloween's Jason Voorhees. "The back stabbers ...." She plunges the knife into Sean and drags him into a supply closet. Christian arrives just in time to save a flatlining Annie. Sean, meanwhile, turns the tables on Colleen, wresting the knife from her and inflicting a fatal

\section{"You can't have your celebrities and eat them, too."}

wound. Christian reaches his dying partner in the nick of time. Just another $\because$ working day at McNamara/Troy, the swish Beverly Hills 90210 nip/tuck shop. Fade to black.

And that, if you're scoring at home, is just the first act of episode 1 , season 5 , part 2 of the durable Emmy- and Golden Globe-winning prime-time edly steamy this season. soap Nip/Tuck, as it ran on Citytv in early March. The series is the creation of former newspaper and Entertainment Weekly reporter Ryan Murphy and the product of the US cable network FX, where it premiered in 2003 with the meaty catchphrase, "So, tell me what you don't like about yourself." The answer, of course, is invariably some physical defect, real or imagined that can be remedied, for a price. As the profoundly shallow Christian tells a gorgeous, thirtyish former lover, whom he's trying to talk into having cosmetic surgery: "When you stop striving for perfection, you might as well be dead."

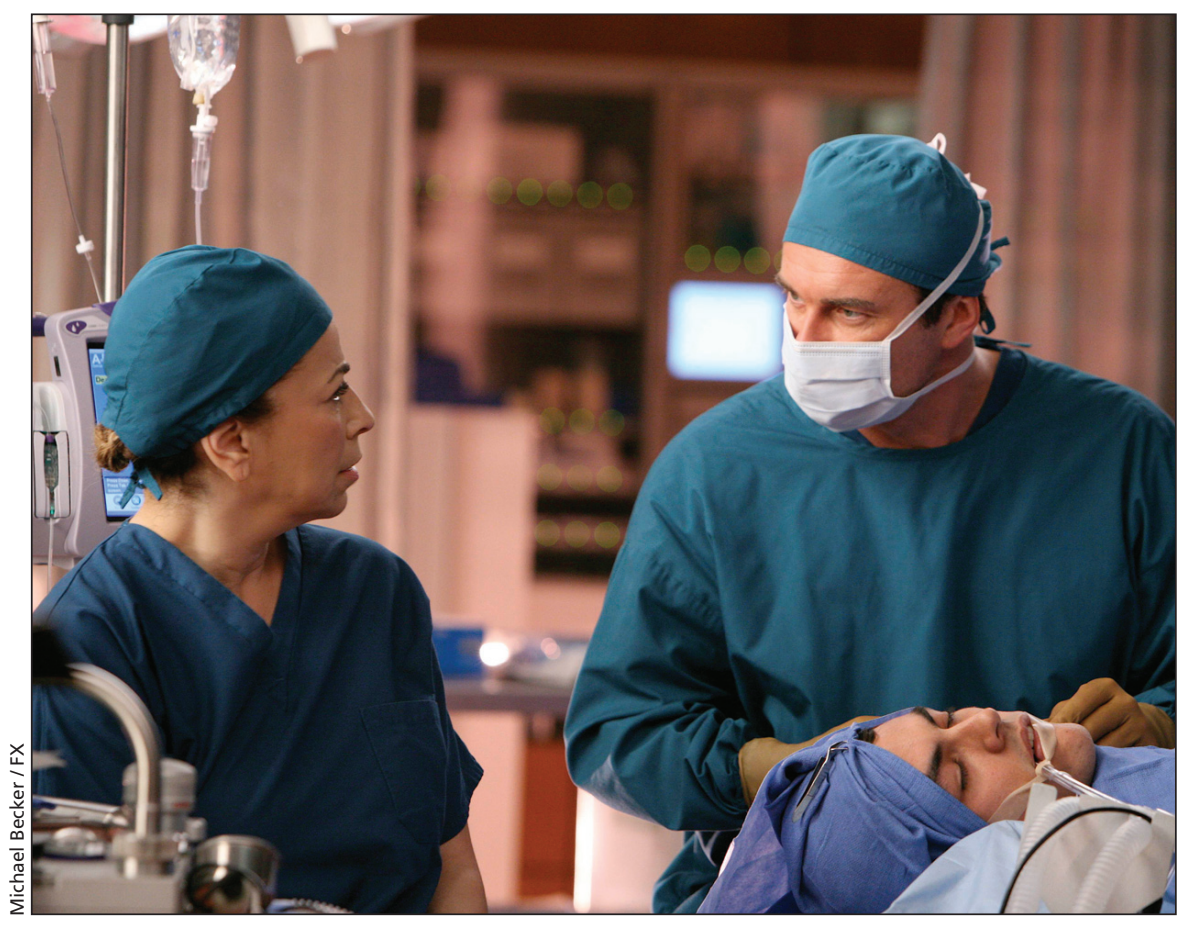

Colleagues Liz Cruz (Roma Maffia) and Christian Troy (Julian McMahon) get unexpect-

Partly, Nip/Tuck is an unblinking and, to the layman at least, medically correct effort. (The production boasts a medical adviser, several consulting plastic surgeons and the most convincing depictions of surgery this side of the Discovery Channel.) And in probing the tangled personal lives of Drs. McNamara and Troy, the show is also anatomically and vernacularly correct. Free from the puritanical constraints of US network television, Nip/Tuck injects the traditional medical drama with previously unimaginable doses of raunchiness - profanity, nudity, simulated sex and downright gore. At the same time, it gleefully plays with every bit of proscribed behaviour from murder to cannibalism.

At its best, the show is a dark, titillating and scalpel-sharp satire on the (North) American obsession with 


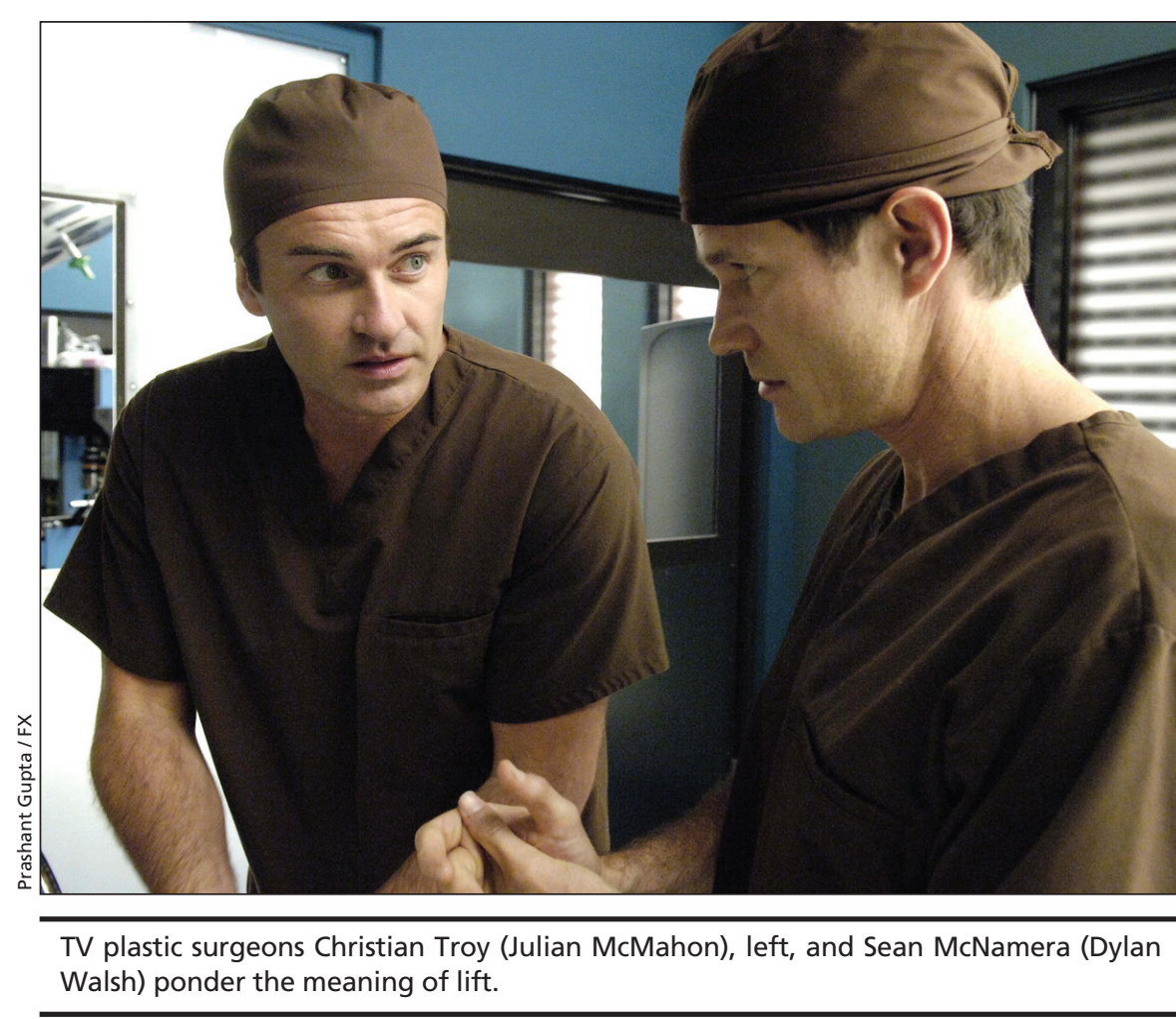

youth, beauty, sex, money, power and celebrity. Over its first couple of seasons, not surprisingly, it became a pleasure, guilty or otherwise, among the less squeamish of those viewers grown bored with conventional network doctor dramas, or never much into them in the first place. Doogie Howser, M.D. it isn't.

But the very ingredients that gave early Nip/Tuck such a refreshing jolt also carried the seeds of its future decline. First, there are only so many taboos to trot out, only so many ways to titillate the hip and épater les bourgeois, before audiences begin to experience an overall numbness. Serial killing, incest, bestiality, self-mutilation — been there, seen that. Ho-hum.

For a show with pretensions to satire, Nip/Tuck also displays a rather cynical dependence on the very commodity it purports to mock. From the beginning, the show has twisted itself in knots trying to write parts for a long line of guests stars clamoring to appear in on the joke - Madonna, Rosie, Nicole, Alanis, Brooke, Morgan Fairchild, Sandra Bullock, Catherine Deneuve, even Richard Chamberlain and Larry Hagman. Celebrities may juice ratings, but the metafictional bag- gage they carry often overwhelms the roles they're supposed to be playing. (Hey, isn't that Portia de Rossi, who just got married to talk-show host Ellen DeGeneres, playing the evil lesbian lover of Joely Richardson, whose mother, Vanessa Redgrave, was also a guest star on the show and whose sister Natasha just died in a skiing accident at Mont Tremblant, Quebec?) There are only so many of these tabloid regulars you can accommodate in a show without defanging it entirely. You can't have your celebrities and eat them, too.

But there's an even more serious malady that's infected the show over the past couple of seasons. To sustain, over the long haul, a drama or comedy - or, as in this case, some Grand Guignol coupling of the 2 - it's character that must drive the story lines, not the reverse. But even Nip/Tuck's principals, the ones we look to for some consistency each week, have been subjected to so many arbitrary nips/tucks that their actions now seem about as natural as a smile on the overly ratcheted face of another former guest star, Joan Rivers.

This season, for instance, the Nip/Tuck brain trust, in a desperate attempt to keep the old autoclave steaming, asks us to buy into an outof-left-field, altar-bound romance between inveterate womanizer Christian and the firm's dowdy, middle-aged lesbian anesthesiologist, Liz Cruz (Roma Maffia). It's a development that seems about as plausible as Seinfeld's George Costanza suddenly decamping for Africa to work with lepers. Add to that is the fact that the callous and misogynistic Christian is now, himself, suffering from - oh, the irony! - stage 2 breast cancer. Sacrificing character and credibility for ungrounded melodrama is a fatal error for any series, even one as unabashedly over-the-top as this. Despite consistently engaging lead performances, sharp direction, and some smartly written scenes, Nip/Tuck has long since toppled off its gurney.

\section{David McDonald \\ Writer/filmmaker \\ Ottawa, Ontario}

Mr. McDonald's most recent documentary, Cereal Thriller, about the unintended consequences of a 1955 cereal-box promotion, premiered on History Television. He is currently working on a book on the same flaky topic.

Nip/Tuck creator Ryan Murphy has also written and directed several feature films, including Running With Scissors, starring Annette Bening, Alec Baldwin and Gwyneth Paltrow. He currently has several films in development, including a "plastic surgery thriller," Face, starring Demi Moore. Murphy's next TV project is Glee, a musical comedy series for the Fox Network. A preview episode airs May 19.

The Nip/Tuck official website (www.fxnetworks.com/shows/originals/nip tuck/) has a feature called "Skin Deep Consultation," where visitors are invited to "select the procedure they think they need and submit their photo for an online consultation. The Nip/Tuck community will evaluate it and give their opinion." Submissions seem about equally split between very average-looking young (mostly) women, apparently seeking either a nose job or a "full-body makeover" and buff, outwardly attractive young people of both sexes. 